\title{
On the viscosity of insulating liquids in a constant electrical field
}

\section{G. Quincke}

To cite this article: G. Quincke (1897) On the viscosity of insulating liquids in a constant electrical field, Philosophical Magazine Series 5, 44:270, 444-444, DOI: 10.1080/14786449708621089

To link to this article: http://dx.doi.org/10.1080/14786449708621089

曲 Published online: 08 May 2009.

Submit your article to this journal $\sqsubset \pi$

Џ Article views: 2

Q View related articles $\sqsubset$ 


\section{[ 444$]$}

\section{Intelligence and Miscellaneous Articles.}

HERTZ WAVES AND METALLIC ENCLOSURES.

To the Editors of the Philosophical Magazine.

GeNTLEMEN,

A MONG other misstatements made in this country I observe $A$ one to the effect that electric waves of moderate length can penetrate a complete metallic enclosure and affect a coherer inside. As shown by me in 1894*, they can readily get in by insulated wires, or by chinks or other interruption of metallic conductivity, but into a cavity really bounded by a conducting wall of fair thickness they do not go.

The statement that they do is a purely misleading one, likely to cause eminent continental physicists to surmise that there may after all be some discovery involved in those sensational newspaper accounts which have not scrupled to use the absurd phrase "Marconi Waves" and to speak of them as if they were novelties unknown to science.

Yours faithfully,

Ouiver J. LodaE.

\section{ON THE VISCOSITY OF INSULATING LIQUIDS IN A CONBTANT ELECTRICAL FIELD. RY G. QUINCKE.}

The results of this inrestigation are as follows :-

I. If solid spheres of insulating material are made to oscillate in an insulating liquid between condenser plates, either parallel or at right angles to the lines of force, the oscillations will be the more strongly damped, the greater is the charge on the plates of the condenser.

II. The difference of the logarithmic decrement of the oseillations with a charged and an uncharged condenser, $\lambda-\lambda_{0}$, is a measure of the increase of viscosity due to electric force, or a measure of the electric viscosity of the liquid at right angles or parallel to the electric lines of force.

III. The electric viscosity at right angles to the lines of electrical force is for ether, for carbon bisulphide, for a mixture of equal volumes of carbon bisulphide and oil of turpentine, and for benzole, nearly proportional to $\mathrm{KP} / a$, where $\mathrm{K}$ is the dielectric constant of the liquid, $P$ the difference of potential, and $a$ the distance between the condenser plates.

IV. Electric viscosity parallel to the electric lines of force is $\mathbf{1 . 5}$ to 6 times smaller than electrical viscosity at right angles to the lines of force.-Wiedemann's Annalen, No. 9, 1897.

* 'The Work of Hertz and his Successors,' published by the Electrician Co., Salisbury Court, Fleet Street, London. 